\section{RESEARCH/FUNDING RELATED OPPORTUNITIES}

Eureka Team

For those who are interested in research but have not had previous experience, the best place to start is a summer research position. Although you could reach the professor of interest directly, it is helpful to get funding from various agencies at the same time. This is usually done between December and January, though some professors are willing to take summer students even later in the year. The following is a list of resources that undergraduate students interested in research could use:

\section{Alberta Heritage Foundation for Medical Research (AHFMR) - usually funds for summer positions; duration $2-4$ months. They also have a Research News subscription that is free, which gives highlights in various areas of research. \\ http://www.ahfmr.ab.ca/}

Natural Sciences and Engineering Research Council of Canada (NSERC) - funds summer positions as well as some co-op programs during the year.

http://www.nserc-crsng.gc.ca/

Canadian Institutes of Health Research (CIHR) - although most of these opportunities are for higher levels of research, there are usually a few undergraduate funding opportunities which are for restricted fields of research - your supervisor will most likely ask you to apply for this one if applicable.

http://www.cihr-irsc.gc.ca/
Eureka

Volume 1, Number 1 (2010)

ARDA International Foundation (AIF) - this is an industry-based foundation that provides some opportunities with funding for undergraduates, but is largely dependent on your supervisor's area of interest and associations.

http://www.arda.org/Content/NavigationMenu2/

Research/Research.htm

CAPS has an online newsletter that could be emailed to you upon subscription. Every now and then they have some workshops on how to write science research resumes. In their Online Job Postings site, there are also some summer research positions from sectors other than the University that you can apply for. Usually those do not require additional outside funding as the company will provide the salary.

There are also some Departmental funding available depending on which Department you approach, so don't forget to go to the departments' sites!!

Finally, if you are interested for research during the term, you can take courses such as Biol 498/499; the prior is one term, the latter is for 2 terms. This is a project based course where the entire course is carried out in a lab. Usually you have to find a supervisor that is willing overlook your project; some departments can arrange for a professor for you.

If I missed any other places where undergraduates can find research opportunities, please email us so we can share it with everyone!!

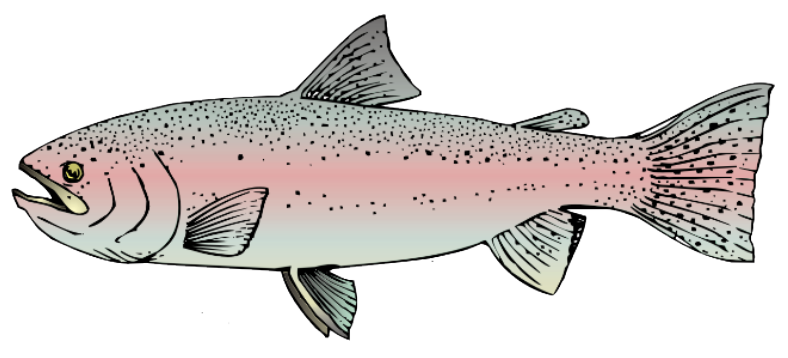




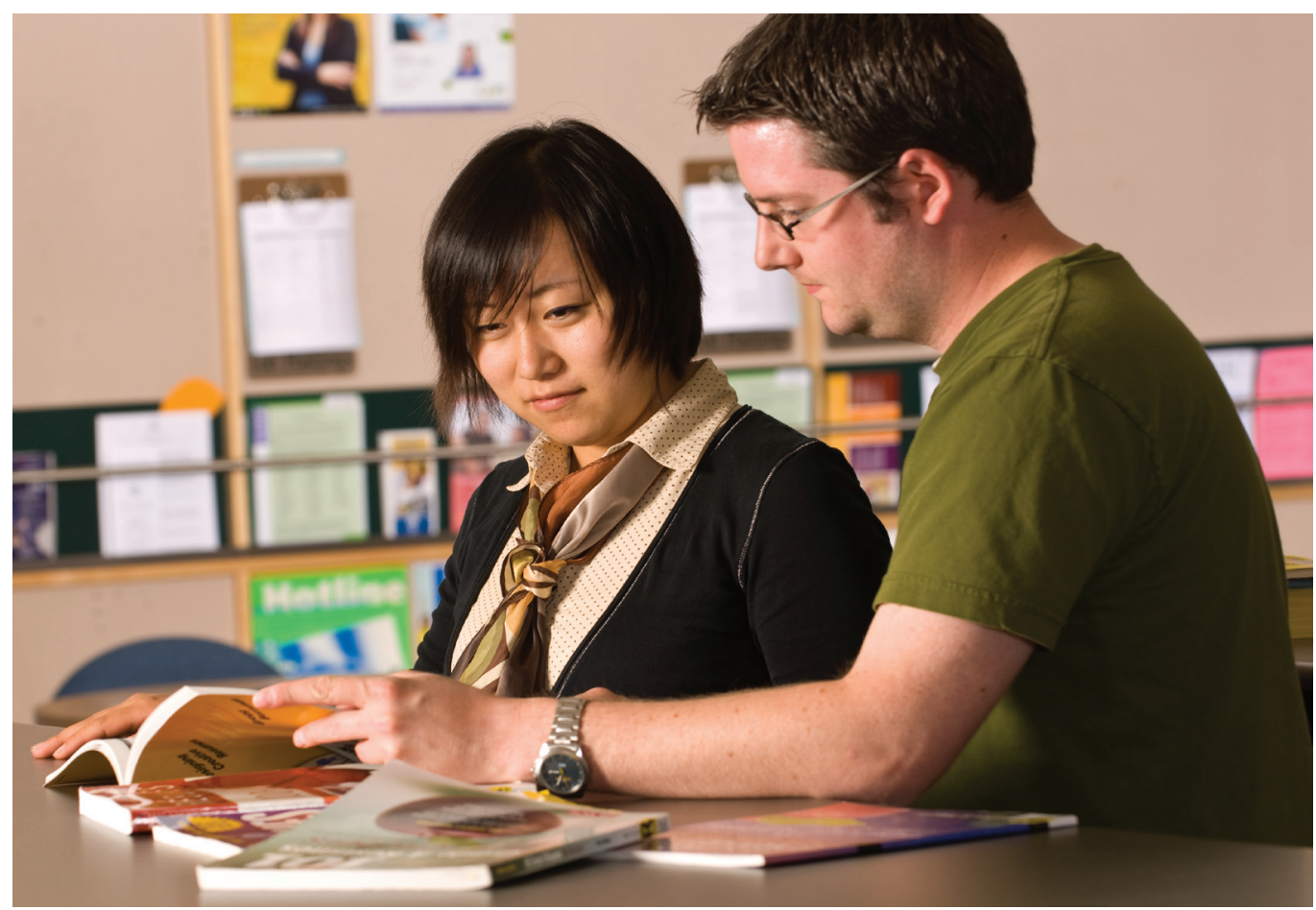

If you are interested in pursuing a career in research, there are a variety of ways CAPS can help including the following workshops and services:

- So, You Want to be an Academic?

- Writing an Effective CV and Cover Letter

- Writing a Personal Statement

- Medical School Interview Help

- Online Job Postings

- Print and Electronic Resources

- Birds of a Feather - connecting students with researchers (coming in Fall 2010) 